\title{
The Influence of Transparency Of Financial Statements, Management of Alms Funds, Social Funds, And The Foundation's Reputation On Donors' Trust in East Java ESQ Humanitarian Institution
}

\author{
${ }^{1}$ Rudi Hartono, ${ }^{2}$ Joko Suyono, ${ }^{3}$ Damarsari Ratnasahara Elisabeth \\ Univeristas Narotama, Surabaya, Indonesia \\ Sekolah Tinggi Ilmu Ekonomi Mahardhika, Surabaya, Indonesia
}

\begin{abstract}
Purpose: This paper aims to The Influence of Transparency of Financial Statements, Management of Alms Funds and Social Funds, and the Foundation's Reputation On Donors' Trust in East Java ESQ Humanitarian Institution.

Design/methodology/approach: The method used is statistic-descriptive and the design used is cross sectional.

Findings: 4 hypotheses are while the other is accepted.

Research limitations/implications: Variables considered in this transparency of financial statements, management of alms funds and social funds, the reputation of the foundation, trust. The scope of analysis techniques used are multiple linear regression, $\mathrm{F}$ significance test, $\mathrm{t}$ significance test, multiple correlation coefficient $(\mathrm{R})$, and multiple determination coefficient $\left(\mathrm{R}^{2}\right)$.

Practical implications: Results show that from the 4 hypotheses proposed.

Originality/value: This paper is original.

Paper type: This paper can be categorized as a case study.
\end{abstract}

Keyword: transparency of financial statements, management of alms funds and social funds, the reputation of the foundation, trust.

\begin{tabular}{lll}
\hline Received & Nov $18^{\text {th }} 2019$ \\
Revised & $:$ February $22^{\text {th }} 2020$ \\
Published & $:$ March $30^{\text {th }} 2020$ \\
\hline
\end{tabular}

\section{INTRODUCTION}

Every person who lives in the world has different conditions in all aspects ranging from the economic aspects of social culture and civilization. One thing that is not the same thing is economic. There are people who are rich and material, but there are also poor and poor lives. But behind it all there is the secret of God that can make people realize that he is nothing. In addition, God wants to test humans whether they are able to optimize all the potential goodness that is given to them. The difference that often 
happens to be a problem for humans, in everyday life often arise turmoil due to gaps between people who are difficult to control.

On February 14, 2014, The President of Republic of Indonesia Susilo Bambang Yudhoyono signed Government Regulation (PP) No. 14 of 2014 concerning the Implementation of Law No. 23/2011 concerning Management of Alms. The presence of this PP has actually been eagerly awaited by national alms practitioners, especially after the decision of the Constitutional Court related to judicial review some time ago. This PP is expected to provide stronger legal certainty in the practice of national alms management, so that existing laws can run operationally. In addition to the form of Islamic religious law, alms is also a form of social correctional and humanitarian charity which can develop in accordance with the development of humanity. So that the level of people who give alms in Indonesia continues to increase every year. This is shown in the table as follows:

Table 1

Total People Who are Entitled to Receive Alms in Indonesia

\begin{tabular}{lcccrr}
\hline \multicolumn{1}{r}{ Year } & $\mathbf{2 0 1 2}$ & $\mathbf{2 0 1 3}$ & $\mathbf{2 0 1 4}$ & $\mathbf{2 0 1 5}$ & \multicolumn{1}{c}{$\mathbf{2 0 1 6}$} \\
\hline Individual & 428 & $20 y .557$ & 9.487 & 42.27 & 104.145 \\
Group & 25 & 2.218 & 3.291 & 3.331 & 5.772 \\
Total & 453 & 22.775 & 12.778 & 45.601 & 109.917 \\
\hline Source: Date National Amil Alms & Agency (BAZNAS) 2016 & &
\end{tabular}

Source: Date National Amil Alms Agency (BAZNAS) 2016

Management of national alms must be in accordance with applicable regulations such as must be transparent in managing financial statements. According to Limbreg et al (2010:15), transparency is the presentation of information that is timely, easily understood, clear, accurate, comparable and easily accessed by interested parties. In addition to transparency, alms management organizations must be able to manage alms funds and social funds properly and professionally. According to Nisam (2014), the management of alms funds and social funds are a management that starts from the collection of funds to the accountability carried out by alms institutions. Effective, professional and responsible alms management which is always the hope of all people. Mature planning, good organization, actualization and good control as a form of professionalism of the alms management organization. Another thing that needs to be considered for alms management organizations, is the reputation of the foundation. According to Bronw et al in Erwin and Abadi (2018), an organization's reputation is a mental association related to an organization that is thought of by people outside the organization. Another thing that needs to be considered for alms management organizations, is the reputation of the foundation. According to Bronw et al in Erwin and Abadi (2018), an organization's reputation is a mental association related to an organization that is thought of by people outside the organization.

Transparency of financial reports is very important to convince and attract the donors, and with the transparency of financial reports, good management of alms funds and social

The Influence of Transparency of Financial Statements, Management of Alms Funds and Social Funds, and the Foundation's Reputation On Donors' Trust in East Java ESQ Humanitarian Institution 
funds and a good reputation, donor trust will be created (Nisam, 2014; Athifah, et al 2018; Herwin and Abadi, 2018). East Java became the province with the second highest number of people who give alms after West Java with the number of people who give alms based on 2016 BAZNAS of 16,217 people. This is a concern for alms fund management institutions to be able to manage and distribute alms in a professional manner.

\section{Financial Report}

\section{LITERATURE REVIEW}

According to Kariyoto (2017: 163), financial statements are reports that are expected to be used as information about the company, and can be combined with other information, such as industry, economic conditions and can provide a better picture related to the prospects and risks of the company. Stakeholders both inside and outside the company, really need financial information that can be obtained from financial statements. This information can be presented by the company in the form of a balance sheet, income statement, statement of changes in capital and cash flow statement of the company. Financial statements are the final product of a series of processes of recording and summarizing business transaction data (Hery, 2015: 3). Financial statements as a summary of financial transactions that occur during the reporting period and made responsibility for the tasks assigned to him by the company (Bahri, 2016: 134).

The purpose of the financial statements is to provide information related to corporate finance, company performance and also the company's cash flow position that can be utilized by interested parties in decision making efforts, as well as reporting the responsibility of management for the use of company resources in achieving its goals (Bahri, 2016: 134 ). The overall purpose of financial statements is to provide information that is useful for stakeholders in making investment and credit decisions in companies. This is because the financial statements provide information about the company's assets, liabilities and capital to help investors and creditors and also other parties in evaluating the strengths and weaknesses of the company's finances.

\section{Transparency of Financial Statements}

According to Limbreg et al (2010: 15), transparency is the presentation of information that is timely, easily understood, clear, accurate, comparable and easily accessed by interested parties. The meaning of transparency does not mean that all information must be shared with other parties, because in an institution or organization it certainly has information that is not public. But it is imperative to disseminate information related to the purpose of the activity, the principles adopted, the workings of environmental impacts and actions to overcome them. Transparency is the first step to increasing accountability. Huda and Nasution (2014: 172), transparency is the availability of information about an organization specifically to interested parties. Transparency as an intuitive idea. So it will be able to help interested parties in making decisions. Nasim (2014), defines transparency as providing

The Influence of Transparency of Financial Statements, Management of Alms Funds and Social Funds, and the Foundation's Reputation On Donors' Trust in East Java ESQ Humanitarian Institution 
information to the public or the public by reason of the public is also entitled to know about where the flow of funds has been paid, as a form of accountability. Maulidiyah and Darno (2019) Transparency is openness and honesty to the public for what has happened to be their right to know in general and comprehensively what must be accountable to the manager of the mandated resources. The concept of accountability is not limited to accountability, but rather to the convenience of the public to access and obtain information, both directly and indirectly as well as oral and written. So that accountability will be created fertile in an environment that prioritizes openness as a basis for accountability or transparency.

Huda and Nasution (2014: 173) state that the expected benefits with transparency are as follows:

1. Minimizing the occurrence of information asymmetry in the organization and the possibility of fraud.

2. Increasing the concern of stakeholders.

According to Limberg et al (2010: 17), there are several impacts when the principle of transparency is not applied, include:

1. The absence of checks and balences, where the principle of transparency is not implemented will make it difficult to control the extent of the planned activities with the implementation.

2. Ignoring obligations, i.e. if there is no definite and clear information related to the rules and standards applied by the organization, then there is a possibility of being carried out by ignoring the obligations.

3. Will give birth to negative issues, where transparency does not work will create issues that corner the organization. The existence of these issues can be exploited by certain parties to pressure the organization.

4. The program does not reach the target group, where there are many cases where the program does not reach the targeted group. This could be due to the information that was only conveyed to village officials which was then not conveyed to the community.

Hasrina and Sy (2018) state several aspects to determine the level of transparency of financial statements, include:

1. Availability of providing financial information in a timely, adequate, clear, accurate and comparable manner, as well as easy public access.

2. The overall disclosure of financial condition.

3 . There is openness without reducing organizational confidentiality.

4. The existence of written organizational policies proportional and communicated to the stakeholders.

According to Nasim (2014), there are five aspects to measuring the transparency of financial statements, namely:

The Influence of Transparency of Financial Statements, Management of Alms Funds and Social Funds, and the Foundation's Reputation On Donors' Trust in East Java ESQ Humanitarian Institution 
1. There are announcements of policies related to income, financial management and assets owned.

2. Ease of accessing reports related to income, financial management and assets owned.

3. Availability of accountability reports in a timely manner.

4. Availability of facilities for public suggestions and proposals.

5. Availability of a system for providing information to the public.

\section{Management of Alms Funds and Social Funds}

According to Santoso and Agustino (2018: 1), alms in terms of fiqh means a certain amount of assets that are required to be handed over to people who are entitled. While social funds are funds issued by a person or organization that is used for social activities. The management according to Saifuddin (2014: 53), is the control of owned resources according to planning, needed to achieve or complete a certain goal. According to the Law of the Republic of Indonesia Number 23 of 2011 concerning with alms which has the alms of better managing alms management in order to increase public confidence in alms institutions or alms bodies. Public participation is needed in the management of alms funds and also social funds. Public accommodation in the management of alms has increased transparency and accountability in the management of religious social funds. In addition, community participation has reduced the potential for misuse of social funds while increasing its effectiveness.

Management of alm will be difficult to succeed if there are no proper arrangements in the collection and distribution. Good management has several elements, namely correct in choosing alms alms and simplifying alms management (Nasution and Qomaruddin, 2015). In addition to the success of alms managers in realizing humanitarian and social goals is to distribute alms as fairly as possible and uphold the correct principles so that alms does not fall on people who are not entitled to receive it. Nasution and Qomaruddin (2015) further explained that the success of zakat managers in realizing humanitarian and social goals is to distribute zakat as fairly as possible and uphold the correct principles so that zakat does not fall on people who are not entitled to receive it.

\section{Foundation Reputation}

Reputation is something that is seen by others. Reputation can also be interpreted as a report card of the work, which is judged by others for what we have done. Someone will give a good or bad value, not we determine (Sutrisno, 2018: 59). Reputation is not an image that can be built in a relatively short time. According to Widodo (2014: 108), the reputation of an organization is related to the good name of the organization. Reputation can form over a relatively long period of time and through achievements that are created. Organizations that have a good reputation, are generally well known and liked by the wider community. A good reputation will make it easier for organizations to be accepted by society. The reputation of an organization that already has a well-known label or

The Influence of Transparency of Financial Statements, Management of Alms Funds and Social Funds, and the Foundation's Reputation On Donors' Trust in East Java ESQ Humanitarian Institution 
organization, will bring pride to the individual concerned. An organization that has a good reputation shows that the organization has good management and professional resources. A person's pride can be rooted, because pride grows if individuals can join an organization (Duha, 2018: 251). According to Bronw et al in Erwin and Abadi (2018), the reputation of an organization is an association of the Minister of Agriculture related to an organization that is thought of by people outside the organization. In this case reputation is only in the minds of the public or the public as an interested party in the organization. If the reputation of the organization has a well-known label, then there will be pride to the individual. The existence of good respect shows that the management in the organization has run well, has reliable human resources and brilliant achievements. According to Widodo (2014: 108), the reputation of an organization is related to the good name of the organization. Reputation can form over a relatively long period of time and through achievements that are created. Organizations that have a good reputation, are generally well known and liked by the wider community. A good reputation will make it easier for organizations to be accepted by society. According to Wulandari and Rasipan (2017), the reputation of an organization is the perception or view of individuals both inside and outside the organization. In this case reputation concerns a person's overall view of the organization as a whole. The more professional the organization is in carrying out its duties and responsibilities, the better the organization's reputation.

According to Hamid and Budianto (2011: 155), there are several strategies that can be carried out by non-profit organizations to create an organizational reputation, including:

1. Make use of mass media

2. Providing a web site

3. Providing the means and energy to consult

4. Counseling or training

5. Making printed matter

6. Conduct intensive communication and consolidation with employees or vounders who have worked together.

According to Miles \& Covin in Wulandari and Rasipan (2017), an organization's reputation can be measured by several aspects, namely:

1. Competence, namely the ability of the organization to carry out its duties and responsibilities in an effort to achieve the planned goals.

2. Credibility, which covers all aspects of the profession owned by the organization. The credibility of the quality and strength of the organization in creating public trust.

3. The good name of the organization, namely the public perception related to the organization's image. 


\section{Donor Trust}

Trust is a person's willingness to rely on other people or organizations where we have confidence in him (Nasim,

2014). The trust someone has in a brand, organization and other objects that have the most important meaning and meaning for that person. Trust can also be interpreted as a person's hopes, assumptions or beliefs about the possibility of action by another party who can bring good, or at least does not harm himself. The principle of trust is a principle that underlies the relationship of the organization or company with the public. In this case the donors channel their funds through the management of alms funds based on the existence of trust, so that the management remains and maintains public trust. Building trust is not an easy thing, because it is obtained if the manager or organization can prove itself to be a professional organization through its capabilities (Umam and Antoni, 2018:113).

Donors as people, organizations or companies that have or are still distributing zakat funds, donations and alms to organizations or institutions channeling zakat funds. There are two factors that can be done to be able to win the trust of donors (Sani, 2010: 70), include:

1. Analysis of the profile and expectations of donors

To be able to fulfill desires and create satisfaction for regulators, the first step is to know their profiles and expectations. Profile knowledge related to introduction to donors. While knowledge related to donor expectations aims to provide appropriate services, in accordance with their expectations.

2. Segmentation, positioning and imaging of institutions

Segmentation of zakat fund distribution institutions can be seen from various

perspectives, include:

a. Geographically, namely international, national, regional, local and company.

b. Demographics, namely gender, age and family status.

c. Psychographic, which is related to economic status, employment, lifestyle, hobbies and others.

Latifah (2018) states that donor trust can be measured by several aspects as folows:

1. Performance in accordance with the wishes or expectations.

2. Confidence related to workmanship that conforms to the standard.

3. Trust is able to provide the right job.

4. Trust is related to consistent service.

5. Trust associated with the organization lasts long.

\section{The influence of financial report transparency on donor trust}

Transparency is built based on freedom to obtain information needed by the public. Transparency implies that annual reports are not only regulated but also publicly accessible. Sharia company theory explains the most important responsibilities of sharia companies to God and the rest are humans (Jayanto and Munawaroh, 2019). Based on the previous explanation, transparency is the responsibility of stakeholders to Allah

The Influence of Transparency of Financial Statements, Management of Alms Funds and Social Funds, and the Foundation's Reputation On Donors' Trust in East Java ESQ Humanitarian Institution 
SWT and other stakeholders related to freedom of access to information in alms management organizations. If the institution is able to present accountable and transparent reporting, it is certain that the public will be satisfied and more confident to distribute alms through alms management organizations and increase people who give alms interest in paying professional alms.

Transparency is a process of openness from the manager or management, especially for public management in establishing access in the management process so that the flow of information both in and out can be balanced (Athifah, et al. 2018). The basis for building transparency is freedom of information.

In the principle of good corporate governance, transparency of the report as one aspect that must be applied by an organization. In a study conducted by Nasim (2014), transparency has a positive and significant effect on public trust. This shows that committee alms institutions which have disclosure of financial statement information will be more easily trusted by the public.

\section{The influence of the management of alms funds and social funds on donor trust} Management of alms funds and social funds requires careful planning, proper organization, actualization and good control as a form of professionalism. Effective management is expected to contribute significantly to solving social, economic and community problems. This can be achieved if good cooperation is established between the alms institutions with the community and also the government.

In Article 1 paragraph 1 of Law in Nisam (2014), alms management is an activity that starts from planning, organizing, implementing and controlling the collection and distribution and utilization of alms. In Law No. 23 of 2011 concerning alms which has the aim to better manage alms management in order to increase public trust in committee alms bodies or committee alms institutions.

Effective, professional and responsible governance of alms funds and social funds is expected for all parties. The existence of careful planning, proper organization, actualization in accordance with good procedures and controls is a picture of the professionalism of alms institutions (Ansori, 2018). Effectiveness in the management of alms is expected to contribute to solving social, economic and social problems.

In a study conducted by Nisam (2014), the management of alms has a significant influence on people who give alms's trust in amil alms institutions. Where the more effective the management of committee alms organizations, will make the public more confident to channel their alms funds to the committee alms.

\section{The influence of the foundation's reputation on donor trust}

Alms management organization is an organization that is based on religious values, so that responsibility is not only for humans but also for God. According to sharia company theory, Allah is the main belief. However, the resources possessed by stakeholders are mandates from God where responsibility is used by means and goals set by God.

The Influence of Transparency of Financial Statements, Management of Alms Funds and Social Funds, and the Foundation's Reputation On Donors' Trust in East Java ESQ Humanitarian Institution 
Alms management organization that has a good reputation shows that the organization is responsible and performs well. The goals of alms management organizations will be achieved if they are oriented in accordance with their vision and mission. If achieved correctly, it can be used as a basic evaluation of people who give alms for alms management organizations and increased interest in paying professional alms through alms management organizations. In line with the theory of planned behavior which explains that human behavior is not only from internal factors but also from subjective norm factors.

Organizations must try to do well planned actions to build an impression in the public mind. Respect will give confidence to the other party. The beliefs created will help increase trust even though there has never been an interaction (McKnight et al in Wulandari and Rasipan, 2017).

In a study conducted by Zainal et al. (2016), reputation has a significant effect on stakeholder confidence in alms institutions. Organizations that have a good reputation and are high in the minds of the community will gain the trust of the community. The higher the reputation, the higher the confidence of the parties concerned.

\section{The influence of the foundation's reputation on donor trust}

Alms management organization is an organization that is based on religious values, so that responsibility is not only for humans but also for God. According to sharia company theory, Allah is the main belief. However, the resources possessed by stakeholders are mandates from God where responsibility is used by means and goals set by God.

Alms management organization that has a good reputation shows that the organization is responsible and performs well. The goals of alms management organizations will be achieved if they are oriented in accordance with their vision and mission. If achieved correctly, it can be used as a basic evaluation of people who give alms for alms management organizations and increased interest in paying professional alms through alms management organizations. In line with the theory of planned behavior which explains that human behavior is not only from internal factors but also from subjective norm factors. Organizations must try to do well planned actions to build an impression in the public mind. Respect will give confidence to the other party. The beliefs created will help increase trust even though there has never been an interaction (McKnight et al in Wulandari and Rasipan, 2017).

In a study conducted by Zainal et al. (2016), reputation has a significant effect on stakeholder confidence in alms institutions. Organizations that have a good reputation and are high in the minds of the community will gain the trust of the community. The higher the reputation, the higher the confidence of the parties concerned.

\section{A. Hypotheses}

The researchers hypothesize the problem above as follows:

H1:Transparency of financial statements influences the trust of donors in East Java LKSEQ.

H2: Management of alms funds and social funds influence donor trust in East Java LKSEQ.

The Influence of Transparency of Financial Statements, Management of Alms Funds and Social Funds, and the Foundation's Reputation On Donors' Trust in East Java ESQ Humanitarian Institution 
H3: The foundation's reputation influences the trust of donors in the East Java LKSEQ. $\mathrm{H} 4$ : Transparency of financial statements, management and principles and social funds and the foundation's reputation influence donor trust in the East Java LKSEQ.

\section{METHOD}

This research is quantitative research. In this study, the population is the whole of East Java LKESQ donors, amounting to 400 donors. While the sampling technique used was the simple random sampling method and obtained a sample size of 200 donors. Retrieval of data in this study in the form of a questionnaire. The data analysis techniques used are multiple linear regression, $\mathrm{F}$ significance test, $\mathrm{t}$ significance test, multiple correlation coefficient $(\mathrm{R})$, and multiple determination coefficient $\left(\mathrm{R}^{2}\right)$.

\section{RESULT AND DISCUSSION}

\section{Multiple Linear Regression}

The following results of multiple linear regression analysis in this study:

Table 2

Results of Multiple Linear Regression Analysis Coefficients $^{\mathrm{a}}$

\begin{tabular}{|c|c|c|c|}
\hline \multirow[t]{2}{*}{ Model } & \multicolumn{2}{|c|}{ Unstandardized Coefficients } & \multirow{2}{*}{$\frac{\text { Standardized Coefficients }}{\text { Beta }}$} \\
\hline & $\mathrm{B}$ & Std. Error & \\
\hline (Constant) & 7.051 & 824 & \\
\hline 1 Transparency of financial statements & .086 & .040 & .087 \\
\hline Management of alms funds and social funds & $\begin{array}{l}.170 \\
.750\end{array}$ & .050 & .186 \\
\hline
\end{tabular}

a. Dependent Variable: Donor trust

From the results of the table above, it can be interpreted that:

1. A constant value of 7.051. This means that without the influence of the variable transparency of financial statements, the management of alms funds and social funds and the reputation of the foundation, the value of donor trust is 7.051.

2. The coefficient value of the transparency variable of the alms fund financial reports and social funds is 0.086 with a positive value. This means that every increase of one unit of the financial statement transparency variable, will have an impact on the increase in the variable of donor trust by 0.086 units, assuming other factors are constant.

3. The coefficient value of the variable management of alms funds and social funds is 0.170 with a positive value. This means that every increase of one unit of Variable management of alms funds and social funds, will have an impact on the increase in the variable trust of donors of 0.170 units, assuming other factors are constant or constant.

The Influence of Transparency of Financial Statements, Management of Alms Funds and Social Funds, and the Foundation's Reputation On Donors' Trust in East Java ESQ Humanitarian Institution 
4. The coefficient value of the foundation's reputation variable is 0.750 with a positive value. This means that each increase in one unit of the foundation's reputation variable will have an impact on the increase in the donor's trust variable by 0.750 units, assuming other factors are constant or constant.

\section{Test of Significance $\mathbf{F}$}

Criteria for decision making in this study is to use a level of significance or significance of 0.05 . Which can be said to have an effect simultaneously if it has a significance value of less than 0.05 . The following are the results of simultaneous tests in this study:

Table 3

Significance Test Results F

ANOVA $^{\mathrm{a}}$

\begin{tabular}{|rl|r|r|r|r|r|}
\hline Model & & Sum of Squares & \multicolumn{1}{|c|}{ Df } & Mean Square & \multicolumn{1}{c|}{ F } & \multicolumn{1}{c|}{ Sig. } \\
\hline \multirow{2}{*}{1} & Regression & 607.045 & 3 & 202.348 & 194.666 & $\mathbf{. 0 0 0}^{\text {b }}$ \\
& Residual & 203.735 & 196 & 1.039 & & \\
& Total & 810.780 & 199 & & & \\
\hline
\end{tabular}

a. Dependent Variable: Donor trust

b. Predictors: (Constant), The reputation of the foundation, Transparency of financial statements, Management of alms funds and social funds.

From the results of the above data calculation, it is known that the significance value of $F_{\text {count }}$ is $0,000>0.05$. This means that simultaneously the variables of financial report transparency, alms fund management and social funds and the foundation's reputation have a significant effect on donor trust in East Java LKESQ.

\section{Significance Test $\mathbf{t}$}

The criteria for decision making in this study is that if the value of the level of significance $\mathrm{t}$-count according to the calculation results is less than or less than 0.05 , then $\mathrm{H} 1$ is accepted. The following partial test results in this study:

Table 4

Significance Test Results $\mathrm{t}$ Coefficients ${ }^{\mathrm{a}}$

\begin{tabular}{|c|c|c|c|c|c|}
\hline \multirow[t]{2}{*}{ Model } & \multicolumn{2}{|c|}{$\begin{array}{l}\text { Unstandardized } \\
\text { Coefficients }\end{array}$} & $\begin{array}{c}\text { Standardized } \\
\text { Coefficients }\end{array}$ & \multirow[t]{2}{*}{$\mathrm{t}$} & \multirow[t]{2}{*}{ Sig. } \\
\hline & B & Std. Error & Bet & & \\
\hline \multirow{3}{*}{$\begin{array}{ll}\text { (Constant) } \\
1 \text { Transparency of financial statements } \\
\text { Management of alms funds and social funds }\end{array}$} & 7.051 & .824 & & 8.554 & .000 \\
\hline & .086 & .040 & .087 & 2.165 & .032 \\
\hline & .170 & .050 & .186 & 3.385 & .001 \\
\hline
\end{tabular}

a. Dependent Variable: Donor trust

1) From the results of the calculation of the transparency variable of the financial statements obtained a significance value of $0.032<0.05$. This means that partially the financial statement transparency variable has a significant influence on donor trust in East Java LKESQ.

The Influence of Transparency of Financial Statements, Management of Alms Funds and Social Funds, and the Foundation's Reputation On Donors' Trust in East Java ESQ Humanitarian Institution 
2) Based on the calculation results shown in the above table, the variable manager of alms funds and social funds has a significance value of $0.001<$ 0.05 . This means that partially the variable management of alms funds and social funds significantly influence the trust of donors in East Java LKESQ.

3) From the calculation of the foundation's reputation variable has a significance value of $0,000<0.05$. This means that partially the foundation's reputation variable has a significant influence on donor trust in East Java LKESQ.

\section{Multiple Coefficient Correlation Test (R)}

Table 5
Multiple Coefficient Correlation Test
Results (R)
Model Summary
Model

From the table above, it is known that the $\mathrm{R}$ value is 0.865 or $86.5 \%$. This means that the ups and downs of the variable of donor trust are influenced by the variable transparency of financial statements, management of alms funds and social funds and the reputation of the foundation by $86.5 \%$, while the remaining $13.5 \%$ is influenced by other variables outside the study.

\section{Multiple Determination Coefficient Test $\left(\mathbf{R}^{\mathbf{2}}\right)$}

The results of the multiple determination coefficient test in this study can be seen in table 5. The results show that the $\mathrm{R}$ Square value of 0.749 or $74.9 \%$. This means that the influence of financial report transparency, the management of alms funds and social funds and the foundation's reputation on donor trust is $74.9 \%$, while the remaining $25.1 \%$ is influenced by other variables outside the study.

\section{Discussion}

\section{The Influence of Financial Statement Transparency on Donors' Trust in East Java LKESQ}

In this study the transparency of financial statements is interpreted as the availability of information related to finance managed by the organization and also as a form of organizational accountability. From the results of hypothesis testing it is known that the 
transparency of financial statements has a significant effect on donor trust in East Java LKESQ. This means that the more transparent the financial management of East Java LKESQ, will make donors and prospective donors more trusting and confident about channeling their funds. Evidence of the transparency of the East Java LKESQ financial report, namely by the ease of access to information both financial statements related to income and also the distribution of funds on the remissions website www.lkesq.or.id, but the transparency of financial statements is still not optimal because on the official website of the foundation only financial statements are presented starting in 2009 to 2014.

If the institution is able to present accountable and transparent reporting, it is certain that the public will be satisfied and more confident to distribute alms through alms management organizations and increase muzaki's interest in paying professional alms. Transparency is a process of openness from the manager or management, especially for public management in establishing access in the management process so that the flow of information both in and out can be balanced (Athifah, et al. 2018). The basis for building transparency is freedom of information. In the principle of good corporate governance, transparency of the report as one aspect that must be applied by an organization.

In line with research conducted by Nasim (2014), transparency has a positive and significant effect on public trust. This shows that committee alms institutions which have disclosure of financial statement information will be more easily trusted by the public. The importance of transparency in organizing alms and alms funds affects the level of trust of donors to alms institutions. Transparency is a demand of the people in institutions that have the duty and authority to manage the alms funds of the people.

\section{The Effect of Management of Alms Funds and Social Funds on Donors' Trust in East Java LKESQ}

The management of alms funds and social funds in this study is interpreted as management that starts from the collection of funds to the accountability carried out by alms distribution institutions. From the results of hypothesis testing, it shows that the management of alms funds and social funds has a significant effect on donor trust in East Java LKESQ. This means that the more professional and effective management of alms funds and social funds that have been donated by donors, the level of trust of donors will increase. Increased donor trust caused by the needs or desires they feel fulfilled.

In Indonesia the management of alms has been regulated in Law 1 paragraph 1 . Whereas in Law No. 23 of 2011 concerning alms which has the aim of better managing alms management in order to increase public trust in committee alms bodies or committee alms institutions. Effective, professional and responsible governance of alms funds and social funds is expected for all parties. The existence of careful planning, proper organization, actualization in accordance with good procedures and controls is a picture of the professionalism of alms institutions (Ansori, 2018). Effectiveness in the management of alms is expected to contribute to solving social, economic and social problems.

The Influence of Transparency of Financial Statements, Management of Alms Funds and Social Funds, and the Foundation's Reputation On Donors' Trust in East Java ESQ Humanitarian Institution 
In line with the results of research conducted by Nasim (2014), where the effective and professional management of alms has a significant effect on donor trust. The more effective the management of committee alms organizations will make the public more confident in channeling alms funds to the committee alms. A donor who has the trust in an institution channeling alms funds, then he will always pay his alms to the institution.

\section{The Influence of the Foundation's Reputation on Donor Trust in East Java LKESQ}

The foundation's reputation in this study is interpreted as a person's overall view of the organization as a whole. From the results of hypothesis testing shows that the foundation's reputation has a significant effect on donor trust in East Java LKESQ. This means that the better the reputation or public awareness of the East Java LKESQ, then their trust will also increase. A reputation cannot be formed in a short time, but can be formed from the foundation's professionalism in carrying out its duties and responsibilities for the resources provided by donors.

Organizations must try to do well planned actions to build an impression in the public mind. In line with the opinion of McKnight et al in Wulandari and Rasipan (2017), having a reputation will give confidence to other parties. The confidence that is created will help increase trust even though there has never been an interaction.

In line with the results of research conducted by Zainal et al (2016), where eputation has a significant effect on stakeholder confidence in alms institutions. Organizations that have a good reputation and are high in the minds of the community will gain the trust of the community. The higher the reputation, the higher the confidence of the parties concerned.

\section{The Influence of Transparency of Financial Statements, Management of Alms Funds and Social Funds and Foundation Reputation on Donors' Trust in East Java LKESQ}

Donor trust in this research is interpreted as a person's trust to donate funds to an organization or institution in the hope that it can be channeled properly. Based on the results of hypothesis testing shows that the transparency of financial statements, the management of alms funds and social funds and the reputation of the foundation significantly influence the trust of donors in the East Java LKESQ. This means that the disclosure of information related to financial reports, effective and professional management as well as positive community support for the foundation, will give trust to donors to donate alms and social funds through East Java LKESQ.

Trust as fundamental to an organization to be able to develop. Trust is an individual's willingness to depend on other parties who are indulged in exchange, which is caused because he has confidence in that party (Athifah, et al 2018). Trust can fly due to individual belief in partners in relationships. Building trust is not an easy thing, because it is obtained if the manager or organization can prove itself to be a professional organization

The Influence of Transparency of Financial Statements, Management of Alms Funds and Social Funds, and the Foundation's Reputation On Donors' Trust in East Java ESQ Humanitarian Institution 
through its capabilities (Umam and Antoni, 2018: 113). The results of the study are proven by an $\mathrm{R}$ value of 0.865 or $86.5 \%$. This means that the ups and downs of the variable of donor trust are influenced by the variable transparency of financial statements, management of alms funds and social funds and the reputation of the foundation by $86.5 \%$, while the remaining $13.5 \%$ is influenced by other variables outside the study.

\section{CONCLUSION}

Based on testing and analyzing the data above, the conclusions obtained in this study are as follows:

1. Financial statement transparency has a significant influence on the trust of donors in East Java ESQ LK. This means that the more transparent in financial management, the prospective donors and donors increasingly trust to channel resources through LK ESQ East Java.

2. Management of alms funds and social funds has a significant influence on donor trust in East Java ESQ LK. Where the more effective and professional management of alms funds and social funds that are late channeled by donors, the donors and prospective donors will increasingly trust to channel their resources through LK ESQ East Java.

3. The foundation's reputation has a significant influence on donor trust in East Java ESQ LK. This means that the ESQ East Java LK foundation is increasingly known and has a positive value in the community, will have an impact on the level of trust of donors.

4. Transparency of financial statements, management of alms funds and social funds and the reputation of the foundation have a significant influence on donor trust in East Java ESQ LK. This means that the more easily the public in accessing financial reports, effective and professional management and supported by positive support for foundations in the community, will increase the trust of donors in channeling funds in LK ESQ East Java.

\section{ACKNOWLEDGMENTS}

This work has no conflict of interest.

\section{REFERENCES}

Ansori, T. (2018). Management of Earning Alms Funds for Empowerment of Mustahik on Lazisnu Ponorogo.

Athifah, et al. (2018). The Influence of Public Accountability and Financial Report

Transparency on Donors' Trust in Foundations PPPA Daarul Qur'an Nusantara.

Journal Homepage Perisai Volume 2 Nomor 1, 54-74.

Duha, T. (2018). Organizational Behavior Issue 1 Issue 1. Yogyakarya: Deepublish.

Entrepreneurship Vol. 14 No. 2 Desember

2017, 121-132.

The Influence of Transparency of Financial Statements, Management of Alms Funds and Social Funds, and the Foundation's Reputation On Donors' Trust in East Java ESQ Humanitarian Institution

Rudi Hartono' Joko Suyono, Damarsari Ratnasahara Elisabeth

Page $\mid 211$ 
Herwin, and Abadi. (2018). The Effect of Company Reputation and Vendor Reputation on Online Purchasing Decisions With Consumer Confidence as an Intermediate Variable. Journal of Management and Business Research (JRMB) Faculty of Economics UNIAT Volume 3 Nomor 3, 353-363.

Huda and Nasution. (2014). Current Issues Lembaga keuangan Syariah. Jakarta: Kencana. International Forestry

Research.

Jayanto and Munawaroh. (2019). The Influences of Reputation, Financial Statement Transparency, Accountability, Religiosity, and Trust on Interest in Paying Alms of Profession. Journal of Accounting Dynamics, 59-69.

Limberg, et al. (2010). Principles for Companies to Implement Social Responsibility. Bogor Barat: Center for

Maulidiyah and Darno. (2019). Effects of Transparency and Accountability of Financial Statements on Donor Trust in Religious Social Foundations. Journal of Applied Accounting Volume 1 Nomor 1. 1-8.

Muslim Herilage Volume 3 Nomor

$1,165-183$.

Nasim, A. (2014). The Influence of Transparency of Financial Statements, Management of Alms, and the Attitude of Managers Against the Level of Trust in People who give alms (Case Study on Amil Alms Institutions in Bandung City). Journal of Accounting And Financial Research, 2 (3), 2014, 550-561.

Nasution and Qomaruddin. (2015). Management Mechanisms of Zakat, Infaq and Sadaqah Funds in Islamic Banks as an Implmentation of the Bank's Social Functions (Case Study at BPR Syariah Amanah Ummah). Juornal Syarikah Volume 1 Numberr 1. 50-60.

Santoso and Agustino. (2018). Zakat as National Resilience.

Yogyakarta: Deepublish. Sutrisno, J. (2018). My father was full of

philosophy. Bandung: Duta.

Umam, and Antoni. (2018). Corporate Action Formation of Sharia Banks: Acquisitions, Conversions and Spinoffs.

Widodo, S. (2014). Mindset Kaya Agen Asuransi. Jakarta: PT Gramedia Widiasrana Indonesia.

Wulandari and Rasipan. (2017). The Role of Reputation in Building Consumer Trust. Journal of Management and

Yogyakarta: UGM

Press.

Zainal, et al. (2016). Reputation, Satisfaction of Alms Distribution, and Service Quality as Determinant of Stakeholder Trust in Alms Institutions. International Journal of Economics and Financial Issues Volume 6

The Influence of Transparency of Financial Statements, Management of Alms Funds and Social Funds, and the Foundation's Reputation On Donors' Trust in East Java ESQ Humanitarian Institution 